\title{
Módszer a talaj szerves-C-tartalmának gyors helyszíni meghatározására
}

\author{
TÓTH TIBOR és SZABÓ BRIGITTA
}

MTA Talajtani és Agrokémiai Kutatóintézet, Budapest és SzIE Mezőgazdaság- és Környezettudományi Kar, Környezetgazdálkodási Intézet, Gödöllő

A talaj szerves-C-tartalmának meghatározása az egyik leggyakoribb talajvizsgálati módszer, mivel a humusztartalom ismerete szükséges a talaj alapvető sajátságainak értelmezéséhez, a talaj hasznosításának tervezéséhez és termékenységének megőrzéséhez is (ORLOV, 1985; NÉMETH, 1996). Emellett a humusznak meghatározó szerepe van a talajszintek elkülönítésében és a talajosztályozásban (SZABOLCS, 1966). Napjainkban egyre több szempontból hangsúlyozzák a humusz jelentőségét, nem csupán a gazdálkodás, ökológia, hanem a globális éghajlati változás szempontjából is. A részletek mellőzésével csupán utalunk a légköri szén csapdázásának (carbon sequestration) kiterjedt külföldi és hazai kutatására (MICHÉLI, 2003).

Mivel a humusz folyamatosan a talajtani kutatások homlokterében van, sőt jelentősége fokozódik, a gyakorlati talajtani szakemberek igénylik a talaj szerves-C-tartalom meghatározásának gyors, pontos, lehetőség szerint a helyszínen is kivitelezhetö módszereit.

Fentieken túl munkánkat a múlt évben elkezdett „A talajképződés és a talajtulajdonságok elörejelzésének regionális vizsgálata statisztikai és térinformatikai eszközökkel" (OTKA T 37731) téma keretében végzett munka terepi vizsgálati választékának kibővítése is motiválta.

A terepen a felvételezők a humusztartalomra hagyományosan a talaj színe alapján következtetnek (HoDGSON, 1974). Több szerző dolgozott ki eljárást a humusztartalomnak a Munsell-színskálával történő becslésére. BLUME és HELSPER (1987) szerint a szervesanyag-tartalomra a színmélységből (Value) jól lehet következtetni. A pontosabb becsléshez a szerzők szerint szükség van a talaj fizikai féleségének ismeretére is. A fizikai féleség szerint három csoportot különítettek el: homok, vályogos homok-homokos vályog, vályog-vályogos agyag, mert ezen csoportoktól függően más a humusztartományok beosztása. A BLUME és HELSPER (1987) által összeállított táblázat nem alkalmazható egy az egyben hazai viszonyaink között. A később ismertetett 60 jellemző magyaror-

Postai cím: Dr. TÓTH TIBOR, MTA Talajtani és Agrokémiai Kutatóintézet, 1022 Budapest, Herman Ottó út 15.E-mail: tibor@rissac.hu 
szági minta esetén csupán 15 talajmintára találtunk egyezést a táblázat által előjelzett és mért humusztartalmak között. Hasonló, hazai viszonyokra érvényes táblázat készítéséhez sok száz minta elemzésére lenne szükség.

Terepen kivitelezhető szervesanyag-becslő módszereket hazánkban nem használnak. A külföldi szakirodalomban két módszer található, mely alkalmas rutinszerü terepi használatra: a lúgos EDTA és a terepi Walkley-Black módszer. A lúgos EDTA módszer azon az elven alapszik, hogy a reagens oldatba viszi a talaj szerves anyagát és a kapott kivonat színének intenzitása arányos a szervesanyag-tartalommal (BOWMAN, 1997). A humuszanyagok sötét színét főként a kinonszerủ szerkezetek és a ketonkötések adják (STEVENSON, 1982). A terepi Walkley-Black módszer hasonlít a hazai módszerkönyvben (BUZÁs, 1988) ismertetett kolorimetriás módszerhez, azzal az eltéréssel, hogy a reagensekből negyed annyi mennyiséget adunk a talajhoz, mint a laboratóriumi eljárás során. A reagensek mennyiségéből adódóan a módszer csak kis (maximum 2,5 \%) humusztartalom esetén javasolt (BOWMAN, 1997; WALKLEY \& BLACK, 1934). A Walkley-Black módszerhez hasonló terepi módszert korábban Magyarországon is leírtak (SZERÉNYI, 1982), ezt azonban kiterjedten nem alkalmazzák.

A terepi humuszmeghatározásra több szerző alkalmasnak találta a spektroszkópiás módszereket. A humuszanyagok kivonására többféle reagens van használatban, ilyenek például az erős bázisok $\left(\mathrm{NaOH}, \mathrm{Na}_{2} \mathrm{CO}_{3}\right)$, semleges sók $\left(\mathrm{Na}_{4} \mathrm{P}_{2} \mathrm{O}_{7}, \mathrm{NaF}\right.$ ), szerves kelátok, hangyasav (STEVENSON, 1982). A látható és UV hullámhosszon történő spektroszkópiás mérések során leggyakrabban a nátrium-hidroxidot használják kivonószerként (BARABANČíKOVÁ et al., 1997). BOWMAN és munkatársai (1991) a szerves szenet spektroszkópiás módszerrel határozták meg. A szerves szén kivonására a szerzők kálium-hidroxidot és nátriumos etilén-diamin-tetraecetsavat $\left(\mathrm{Na}_{2} \mathrm{EDTA}\right)$ használtak. A kivonószerrel két órán keresztül rázatták a talajt $85{ }^{\circ} \mathrm{C}$-on, majd szürés után a kivont anyag abszorbanciáját $260 \mathrm{~nm}$-nél mérték meg. A módszerrel kapott eredmény és a száraz égetés eredménye között statisztikailag szoros összefüggést kaptak. A spektroszkópiás méréseknél figyelembe kell venni a különböző talajok kialakulását, amely hatással van a kivonatok abszorbanciájára (GIESEKING, 1975), mivel a különböző talajtípusok esetén eltérő a huminsavak és fulvosavak aránya.

$\mathrm{Az}$ általunk javasolt új módszer laboratóriumi előzményét BALLENEGGER (1958) ismerteti. A kálium-permanganátból savas közegben oxigén szabadul fel, amely a szerves vegyületek szenét eloxidálja (BALLENEGGER, 1958; PATAKI \& ZAPP, 1972). Újításunk lényege, hogy a reakció során felszabadult $\mathrm{CO}_{2}$ menynyiségét kézi müszerrel a terepen megmérjük és ez alapján következtetünk a talaj szerves-C-tartalmára.

Fentieknek megfelelően munkánk célja a korábban bevezetett és az újonnan kidolgozott módszerek alkalmasságának előzetes, laboratóriumi tesztelése volt. A terepi alkalmazás tapasztalatairól egy későbbi közleményben számolunk be. 


\section{Anyag és módszer}

\section{A mintakollekció}

A laboratóriumban vizsgált $60 \mathrm{db}, 10 \%$-nál kisebb humusztartalmú reprezentatív talajmintát az MTA TAKI Agrokémiai és Növénytáplálási Osztályától, Kádár Imre talajgyüjteményéből kaptuk kiszárított, elporított, átszitált $(<0,50$ $\mathrm{mm}$ ) állapotban. A laboratóriumban ezeken a mintákon végeztük el az elemzést és ezeket használtuk a megelőző módszerfejlesztésre is.

A módszerek megbízhatóságának vizsgálatához a fentiekből 12 mintát választottunk ki, ezek humusztartalmát a tesztelt módszerekkel négy ismétlésben határoztuk meg. A kiválasztás úgy történt, hogy: a humusztartalom alapján sorba állított 60 minta közül minden hatodikat kivettük.

\section{A vizsgálati módszerek}

Alapmódszernek a szabvány szerinti Tyurin-módszert tekintettük, ennek az általunk alkalmazott változata csupán annyiban különbözött a BUZÁs (1988) által javasolttól, hogy a bemért talajmennyiség kisebb volt: 0,1-0,5 g közé esett.

A „terepi Walkley-Black” és „lúgos EDTA” módszert BowMAN-tól (1997) vettük át.

A , kálium-permanganátos szén-dioxid-fejlesztés” módszer. - Az újonnan kifejlesztett módszer a nedves égetés során a lombik légterébe jutott szén-dioxid koncentrációját méri és ennek alapján becsüli a talaj szerves-C-tartalmát. A talajt savas kálium-permanganát oldattal kezeljük, majd a lefedett edényben három perc elteltével a képződött szén-dioxid-koncentrációt hordozható infravörös érzékelővel ellátott berendezéssel megmérjük. A talaj karbonáttartalmának hatását párhuzamos, csak kénsav hozzáadásával kivitelezett reakcióval vesszük figyelembe.

A szükséges eszközök: kanál, mérleg, mérőhenger, gumidugó (közepén kifúrt), $300 \mathrm{ml}$-es Erlenmeyer lombik, $\mathrm{CO}_{2}$-mérő müszer, stopper, ragasztószalag.

Reagensek: $0,5 \mathrm{~N} \mathrm{KMnO}_{4}$ oldat, $18 \%$-os $\mathrm{H}_{2} \mathrm{SO}_{4}$ oldat.

Eljárás:

1. A szervetlen karbonáttartalom meghatározása: $0,1-1$ g talajra $25 \mathrm{ml} 18 \%$ os $\mathrm{H}_{2} \mathrm{SO}_{4}$-ot öntünk, jól összerázzuk, lezárjuk a lombikot gumidugóval és állni hagyjuk. 3 perc múlva megmérjük a lombikban fejlődött $\mathrm{CO}_{2}$ koncentrációját a müszerrel.

2. A szerves-C-tartalom meghatározása: $0,1-1 \mathrm{~g}$ talajra $10 \mathrm{ml} \mathrm{KMnO}_{4}$ oldatot és $25 \mathrm{ml} 18 \%$-os $\mathrm{H}_{2} \mathrm{SO}_{4}$-ot öntünk, jól összerázzuk, lezárjuk a lombikot gumidugóval és állni hagyjuk. 3 percet várunk, majd müszerrel megmérjük a fejlődött $\mathrm{CO}_{2}$ koncentrációját.

Minden mérés elött megmérjük a légkör háttér $\mathrm{CO}_{2}$ koncentrációját is, amelyet kivonunk a mért koncentrációkból. A szervesanyag-mennyiség becslése a 
humuszból és a $\mathrm{CaCO}_{3}$-ból fejlödött $\mathrm{CO}_{2}$-mennyiségek különbségének számítása alapján történik.

A karbonátokat és a szerves-C-tartalmat ugyanolyan talajmennyiséggel határozzuk meg. Ha különböző talajok szerves-C-tartalmát hasonlítjuk össze, a $\mathrm{CO}_{2}$-koncentráció különbséget a bemért talajtömegnek megfelelően $1 \mathrm{~g}$ talajmennyiségre számítjuk át.

A $\mathrm{CO}_{2}$-koncentrációt Anagas CD 98 berendezéssel mértük. A müszer két hullámhosszon, infravörös sugarakkal végzi a meghatározást. A vizsgálandó levegő szivattyú segítségével jut el az érzékelő részhez. A koncentrációt a müszer ppm-ben adja meg. Mivel a müszer kicsi és könnyü, a terepi mérésekre alkalmas (Environmental Instruments, 1988).

A talaj szerves-C-tartalmát John Kimble határozta meg száraz égetéses (dry combustion) módszerrel (USDA, 1996).

A humusztartalom mellett vizsgáltuk a talajok $\mathrm{CaCO}_{3}$-tartalmát (Scheiblerféle kalciméterrel) és nedves színét (Munsell-színskálával). A Munsell-féle színskála „Value” értékére a „színmélység”, a „Chroma” értékére a „színteltség”" kifejezésekkel hivatkozunk (CSAPÓ \& CSAPÓ, 1980 nyomán). Ugyanakkor felhívjuk a figyelmet arra, hogy a német szakirodalom ezekkel a kifejezésekkel nem teljesen egyező terminus technicus-okat használ. SCHEFFER és SCHACHTSCHABEL (1976) a Value-ra Helligkeit, a Chroma-ra Intensität, de BLUME és HELSPER (1987) a Value-ra Farbhelligkeit, a Chroma-ra a Farbtiefen kifejezést használja. Ez utóbbi ellentétes az általunk átvett, Csapó-Csapó-féle szóhasználattal.

Statisztikai és adatelemzési módszerek. - A statisztikai vizsgálatok során előzetes adatelemzést végeztünk az adatok eloszlásának, szórásának, összefüggéseinek feltárására. A módszerek közötti összefüggést Pearson-féle korrelációs koefficienssel fejezzük ki.

A módszerek megbízhatóságának értékeléséhez négy-négy ismétlés alkalmazásával kiszámoltuk a variációs koefficiens (CV \%) értékét. Az egyes mintákra kapott CV-értékeket a $12 \mathrm{db}$ ismétlésre kiválasztott mintára átlagoltuk, ez az érték jellemezte a módszerek megbízhatóságát.

\section{Eredmények}

A módszerek eredményeit a hazai szabvány által elöírt Tyurin-módszerrel meghatározott szervesanyag-tartalomhoz hasonlítottuk. A vizsgálati eredmények alapstatisztikai paramétereit az 1. táblázat mutatja be, ebből kitünik, hogy a kiválasztott 60 minta kellően reprezentálja a hazai talajok humusz- és $\mathrm{CaCO}_{3}$ tartalmát is. A különböző vizsgálati paraméterek gyakorisági eloszlása - a Tyurin-módszert kivéve - a normál eloszlást jól közelítette, ezért a humusztartalmat tízes alapú logaritmussal transzformáltuk és így is bevontuk a korreláció- 
számításba (1. ábra). A száraz égetéses módszerrel meghatározott szerves-Ctartalom és a Tyurin-módszerrel meghatározott humusz \% között a korrelációs koefficiens értéke 0,86 volt, ezért a továbbiakban a hazai szabvány szerinti Tyurin-módszerhez hasonlítottuk az új módszert.

\section{1. táblázat}

A vizsgált 60 minta alapstatisztikai paraméterei

\begin{tabular}{|c|c|c|c|c|c|}
\hline $\begin{array}{c}(1) \\
\text { Módszer }\end{array}$ & $\mathrm{n}$ & $\begin{array}{c}(2) \\
\text { Mini- } \\
\text { mum }\end{array}$ & $\begin{array}{c}(3) \\
\text { Maxi- } \\
\text { mum }\end{array}$ & $\begin{array}{l}\text { (4) } \\
\text { Átlag }\end{array}$ & $\begin{array}{l}(5) \\
\text { Szórás }\end{array}$ \\
\hline a) Száraz színmélység (Value)* & 60 & 3 & 7 & 4,70 & 1,01 \\
\hline b) Száraz színteltség (Chroma)* & 60 & 1 & 6 & 3,07 & 1,16 \\
\hline c) Nedves színmélység (Value)* & 60 & 2 & 5 & 3,01 & 0,87 \\
\hline d) Nedves színteltség (Chroma)* & 60 & 1 & 6 & 2,87 & 0,95 \\
\hline e) Szerves szén \% száraz égetéssel & 60 & 0,19 & 5,53 & 1,854 & 1,31 \\
\hline f) Humusz $\%$ Tyurin szerint & 60 & 0,08 & 8,70 & 2,79 & 1,85 \\
\hline g) Terepi Walkley-Black abszorbancia & 60 & 0,056 & 0,841 & 0,508 & 0,185 \\
\hline h) Terepi Walkley-Black sorrend** & 55 & 1 & 55 & 28,00 & 16,02 \\
\hline i) Lúgos EDTA sorrend** & 60 & 1 & 60 & 30,97 & 18,11 \\
\hline j) Lúgos EDTA transzmittancia & 60 & 0 & 97,3 & 21,15 & 25,99 \\
\hline k) $\mathrm{CaCO}_{3} \%$ Scheibler-féle kalciméterrel & 60 & 0,19 & 55,25 & 5,67 & 10,68 \\
\hline 1) Kénsavas $\mathrm{CO}_{2}$-fejlesztés, ppm & 60 & 980 & 9690 & 2856,33 & 1891,38 \\
\hline $\begin{array}{l}\text { m) Kálium-permanganátos } \mathrm{CO}_{2} \text {-fejlesztés, } \\
\text { delta } \mathrm{ppm} / \mathrm{g} \text { talaj }\end{array}$ & 60 & -240 & 5690 & 1195,83 & 953,83 \\
\hline n) $\log$ humusz $\%$, Tyurin szerint & 60 & $-1,10$ & 0,94 & 0,34 & 0,35 \\
\hline
\end{tabular}

Megjegyzés: *Munsell-színskálával meghatározott paraméter. **A színtónus alapján a legvilágosabbtól a legsötétebbig rendezett minták sorrendje

A

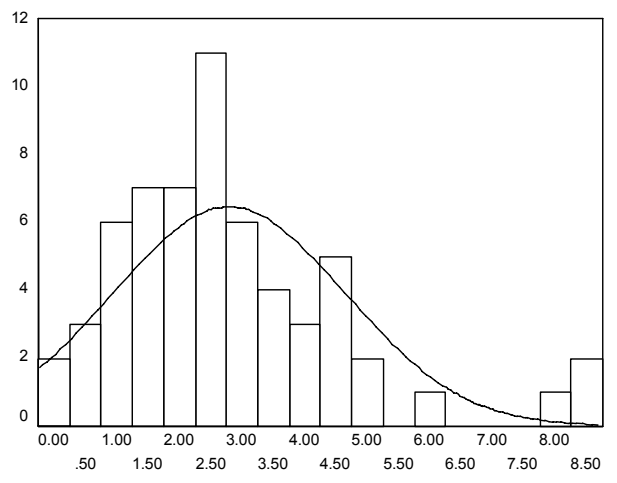

B

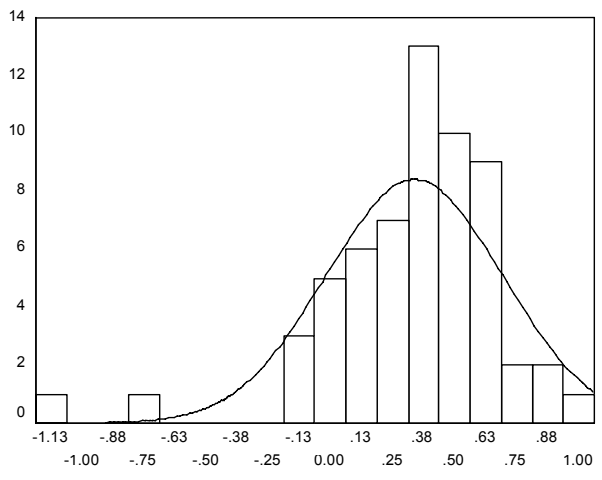

1. ábra

A Tyurin szerinti humusztartalom gyakorisági eloszlása transzformáció nélkül (A) és logaritmizálva (B) 
A talajminták színének jelentősége a humusztartalom becslése szempontjából

Megállapítottuk, hogy a nedves színmélység (Value) és a humusz \% logaritmusa között szignifikáns összefüggés van, amint azt a 2. táblázat és 2. ábra bemutatja.

\section{2. táblázat}

A talaj humusztartalma (Tyurin szerint) és a színe között meghatározott korrelációs koefficiensek

\begin{tabular}{|c|c|c|c|c|}
\hline \multirow{2}{*}{$\begin{array}{c}\text { (1) } \\
\text { Paraméter }\end{array}$} & $\begin{array}{c}(2) \\
\text { Nedves }\end{array}$ & $\begin{array}{c}(3) \\
\text { Száraz }\end{array}$ & $\begin{array}{c}(2) \\
\text { Nedves }\end{array}$ & $\begin{array}{c}(3) \\
\text { Száraz }\end{array}$ \\
\hline & \multicolumn{2}{|c|}{ (4) színmélység (Value) $^{+}$} & \multicolumn{2}{|c|}{ (5) színteltség (Chroma) $)^{+}$} \\
\hline a) Humusz $\%$ & $-0,637 * *$ & $-0,541 * *$ & $-0,347 * *$ & $-0,399 * *$ \\
\hline b) Log humusz $\%$ & $-0,733 * *$ & $-0,587 * *$ & $-0,189$ & $-0,267 *$ \\
\hline c) Nedves színmélység ${ }^{+}$ & 1 & $0,835^{* *}$ & $0,418^{* *}$ & $0,507 * *$ \\
\hline d) Száraz színmélység ${ }^{+}$ & & 1 & $0,470 * *$ & $0,550 * *$ \\
\hline e) Nedves színteltség ${ }^{+}$ & & & 1 & $0,809 * *$ \\
\hline
\end{tabular}

Megjegyzés: **: 0,01, *: 0,05 szinten szignifikáns a korreláció. ${ }^{+}$: Munsell-színskálával meghatározott paraméter

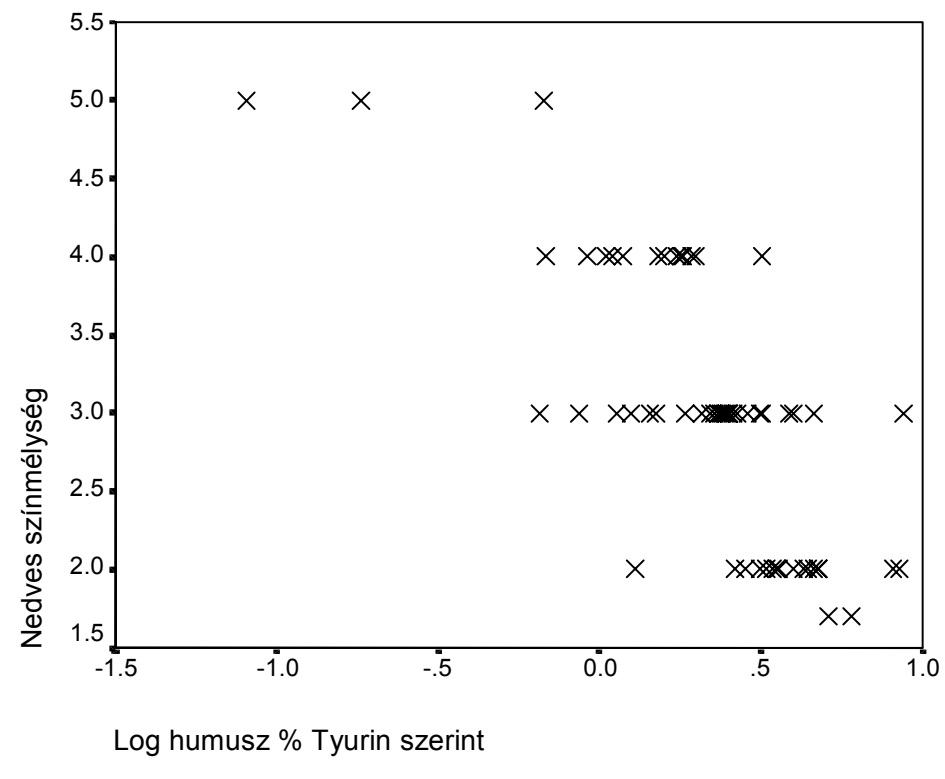

2. ábra

Összefüggés a nedves színmélység (Value) és a Tyurin szerinti humusztartalom logaritmusa között 
A humusztartalomnak a szín alapján történő becslése ígéretes módszernek tekinthetö. A pontosabb humusztartalom-becsléshez a fizikai féleség ismerete is szükséges.

\section{A terepi Walkley-Black módszer laboratóriumi vizsgálata}

A nagyobb szervesanyag-tartalmú talajok esetén a módszer leírása alapján adagolt kálium-bikromát mennyisége nem elegendő a szerves anyag eloxidálásához, így a spektrofotométerrel mért eredmények nem pontosak azon talajok

\section{3. táblázat}

A terepi Walkley-Black módszer és a Tyurin szerinti humusztartalom között meghatározott korrelációs koefficiensek az összes (A), ill. a 2,5 \%-nál kisebb humusztartalmú minták (B) esetén

\begin{tabular}{|c|c|c|c|c|}
\hline \multirow{2}{*}{$(1)$} & \multicolumn{2}{|c|}{ A. } & \multicolumn{2}{c|}{ B. } \\
\cline { 2 - 5 } Paraméter & $\begin{array}{c}(2) \\
\text { Terepi Walk- } \\
\text { ley-Black } \\
\text { abszorbancia }\end{array}$ & $\begin{array}{c}\text { Terepi Walk- } \\
\text { ley-Black } \\
\text { sorrend }\end{array}$ & $\begin{array}{c}\text { Terepi Walk- } \\
\text { ley-Black } \\
\text { abszorbancia }\end{array}$ & $\begin{array}{c}\text { Terepi Walk- } \\
\text { ley-Black } \\
\text { sorrend }^{+}\end{array}$ \\
\hline $\begin{array}{c}\text { a) Humusz \%, Tyurin } \\
\text { szerint } \\
\text { b) Log humusz \%, } \\
\begin{array}{c}\text { Tyurin szerint } \\
\text { c) Terepi Walkley- } \\
\text { Black abszorbancia }\end{array}\end{array}$ & $0,728^{* *}$ & $0,872^{* *}$ & $0,661^{* *}$ & $0,811^{* *}$ \\
\hline
\end{tabular}

Megjegyzés: **: 0,01 szinten szignifikáns a korreláció. ${ }^{+}$:A színtónus alapján a legvilágosabbtól a legsötétebbig rendezett minták sorrendje

esetében, melyek oldatának színe az oxidálószer hozzáadása után zöld lesz. Nagy szervesanyag-tartalom esetén az oldat zavaros lesz, mivel a bikromát a szerves anyagnak csak egy részét képes eloxidálni. Az oldatok színe alapján történő szervesanyag-becslés viszonylag megbízható (3. táblázat). A Tyurin szerinti humusztartalommal a legszorosabb összefüggést a módszer szerint meghatározott sorrend mutatta (3. ábra).

A módszert BowMAN (1997) 2,5 \%-nál kisebb humusztartalmú talajok vizsgálatára ajánlja, ezért kiszámoltuk, hogy az ebbe a humusztartományba eső minták esetén mekkora a terepi Walkley-Black és a Tyurin szerinti humusztartalom közötti korrelációs koefficiens (3. táblázat, 4. ábra). A korrelációs koefficiens értékében növekedést nem tapasztalunk, a módszerrel a szükebb és tágabb értéktartományú mintasorozatokban hasonló nagyságú korrelációs koefficienseket számoltunk. 


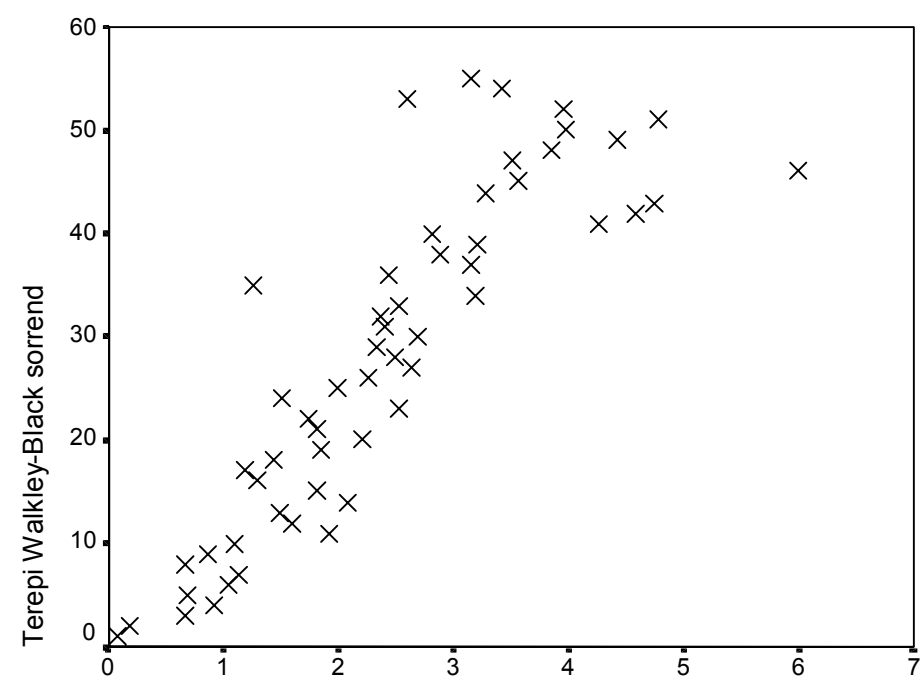

Humusz \% Tyurin szerint

$$
\text { 3. ábra }
$$

Összefüggés a terepi Walkley-Black sorrend és a Tyurin szerinti humusztartalom között

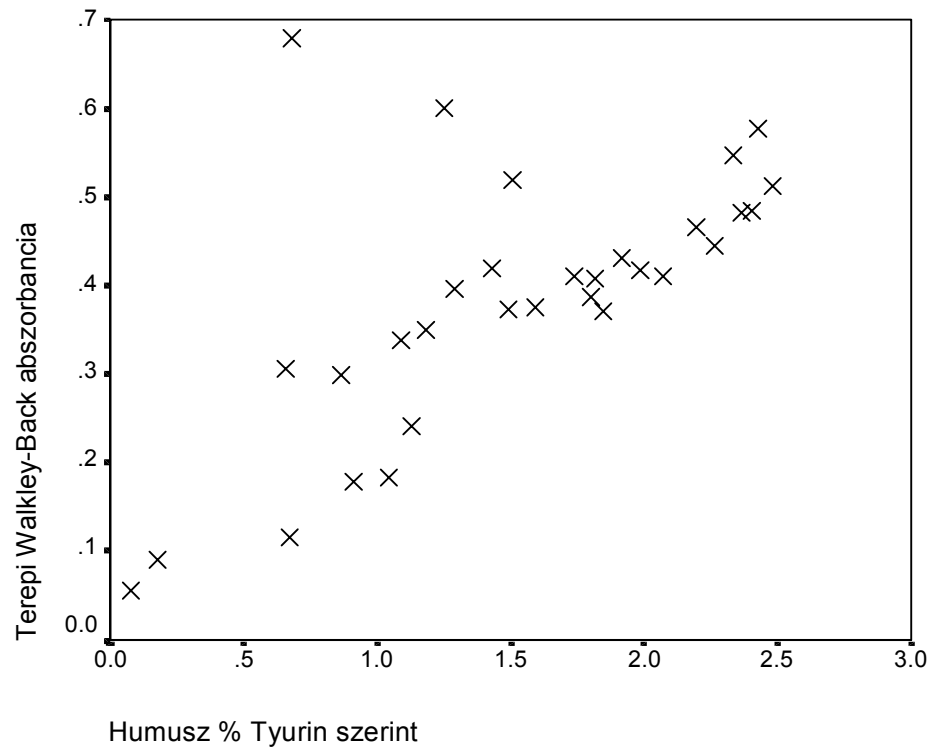

$$
\text { 4. ábra }
$$

Összefüggés a terepi Walkley-Black abszorbancia és a Tyurin szerinti humusztartalom között 2,5 \%-nál kisebb humusztartalmú minták esetén 


\section{A lúgos EDTA módszer laboratóriumi vizsgálata}

A lúgos EDTA módszerrel a minták sötétségi sorrendje, transzmittanciája és a Tyurin szerinti humusztartalom között szignifikáns korrelációt számoltunk (4. táblázat). A minták $\mathrm{CaCO}_{3}$-tartalma további fontos befolyásoló tényező, mivel a $\mathrm{CaCO}_{3}$ megvédi a szerves kötésben lévő szenet az EDTA-tól. A savas közegben

\section{4. táblázat}

A lúgos EDTA módszer és a Tyurin szerinti humusztartalom között meghatározott korrelációs koefficiensek a 2,5\%-nál kisebb humusztartalmú minták esetén

\begin{tabular}{|c|c|c|c|}
\hline & $\begin{array}{c}(1) \\
\text { Lúgos EDTA } \\
\text { transzmittancia }\end{array}$ & $\begin{array}{c}(2) \\
\text { Log lúgos EDTA } \\
\text { transzmittancia }\end{array}$ & $\begin{array}{c}(3) \\
\text { Lúgos EDTA sor- } \\
\text { rend }^{+}\end{array}$ \\
\hline $\begin{array}{c}\text { a) Humusz \% Tyurin } \\
\text { szerint }\end{array}$ & $-0,593^{* *}$ & $-0,508^{* *}$ & $0,646^{* *}$ \\
b) Log humusz \% \\
$\begin{array}{c}\text { Tyurin szerint } \\
\text { c) Lúgos EDTA } \\
\text { transzmittancia }\end{array}$ & $-0,783^{* *}$ & $-0,570^{* *}$ & $0,723^{* *}$ \\
d) Log lúgos EDTA \\
transzmittancia
\end{tabular}

Megjegyzés: **: 0,01 szinten szignifikáns a korreláció. ${ }^{+}$:A színtónus alapján a legvilágosabbtól a legsötétebbig rendezett minták sorrendje

oldatba került kalcium komplexet képez az EDTA-val, így az annak a lekötésére fogy el, következésképpen a nagy $\mathrm{CaCO}_{3}$-tartalmú talaj oldata világosabb lesz annál, mint szervesanyag-tartalma alapján várhatnánk. A nagy szervesanyagtartalmú talajok között nehéz különbséget tenni. (Ebben az esetben segíthet, ha a kémcsövet lámpával átvilágítjuk.)

A legszorosabb összefüggést a lúgos EDTA transzmittancia és a Tyurin szerinti humusztartalom logaritmusa között találtuk (5. ábra).

\section{A szén-dioxid-fejlesztéses módszer}

Kénsavas $\mathrm{CO}_{2}$-fejlesztés. - $\mathrm{A} \mathrm{CaCO}_{3}$-ból felszabadult $\mathrm{CO}_{2}$ koncentrációja (amit a hordozható müszerrel mértünk) és a Scheibler-féle módszerrel mért $\mathrm{CaCO}_{3} \%$ között statisztikailag szignifikáns korreláció volt $(0,721)$. Problémát jelent, hogy feltételezhetően a $\mathrm{CaCO}_{3}$ felületén a reakció következtében egy kevéssé oldódó $\mathrm{CaSO}_{4}$-bevonat alakul ki a kénsav hatására, mely megvédi a kéreg alatti $\mathrm{CaCO}_{3}$-ot a bontástól, így a müszerrel kapott karbonáttartalom a valódinál kisebb lesz. További problémát jelent, hogy az általunk használt kénsav koncentrációja, valamint a meghatározás három perces időtartama valószínủleg nem elegendő az összes karbonát eloxidálásához. Munkánk során feltéte- 


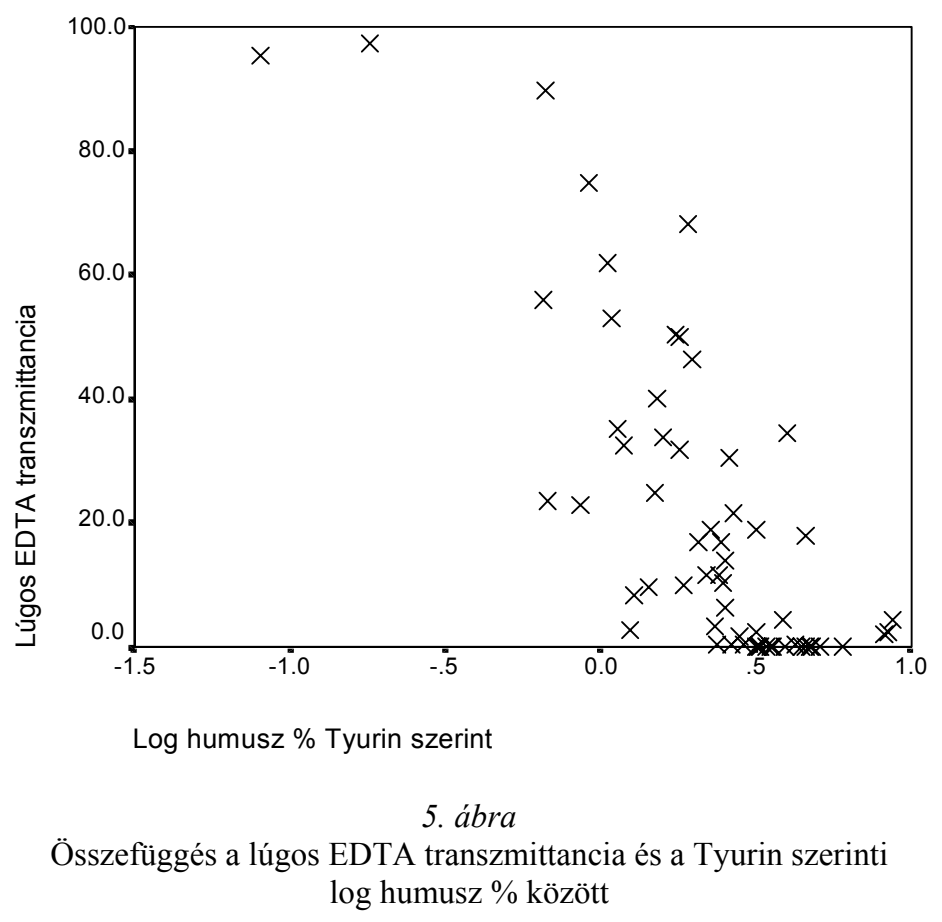

leztük az arányosságot: ugyanannyi idő alatt a nagyobb karbonáttartalmú talajból arányosan több $\mathrm{CO}_{2}$ fejlődik.

A képződött szén-dioxid-koncentrációkból a reakcióegyenletek és az általános gáztörvény alapján kiszámoltuk az elbontott $\mathrm{CaCO}_{3}$-mennyiséget, és megállapítottuk, hogy a kalciméteres meghatározáshoz képest a talajminták összes $\mathrm{CaCO}_{3}$-tartalmának 12,5\% \%-a mérhető a kidolgozott módszerrel.

A 6. ábrán látható összefüggés statisztikailag szignifikáns, kis karbonáttartalom esetén azonban a kénsav által felszabaduló $\mathrm{CO}_{2}$ mennyiségében nem tapasztaltunk szoros összefüggést. Erre az egyik magyarázat az lehet, hogy a kis karbonáttartalom esetén megmaradó karbonátok formája stabilabb, ami azt jelenti, hogy vagy nagyobb savkoncentráció hatására vagy a bontásra alkalmasabb savval $(\mathrm{HCl})$, avagy hosszabb idő elteltével bomlanak le.

A 6. ábrához kapcsolódó, az origón átmenő egyenes regressziós egyenlete a következő: $\mathrm{CaCO}_{3}(\%)=211 \cdot$ Kénsavas $\mathrm{CO}_{2}$-fejlesztés (delta ppm/g talaj), $\mathrm{R}=$ 0,744 .

Kálium-permanganátos $\mathrm{CO}_{2}$-fejlesztés. - A Tyurin szerinti humusztartalom és a kálium-permanganátos $\mathrm{CO}_{2}$-fejlesztés között számolt korrelációs koefficiens $(0,76) 1 \%$-os megbízhatósági szinten $(<0,01)$ szignifikáns volt a mintakollekcióra (5. táblázat). Egyes nagy karbonáttartalmú minták esetén nem volt 


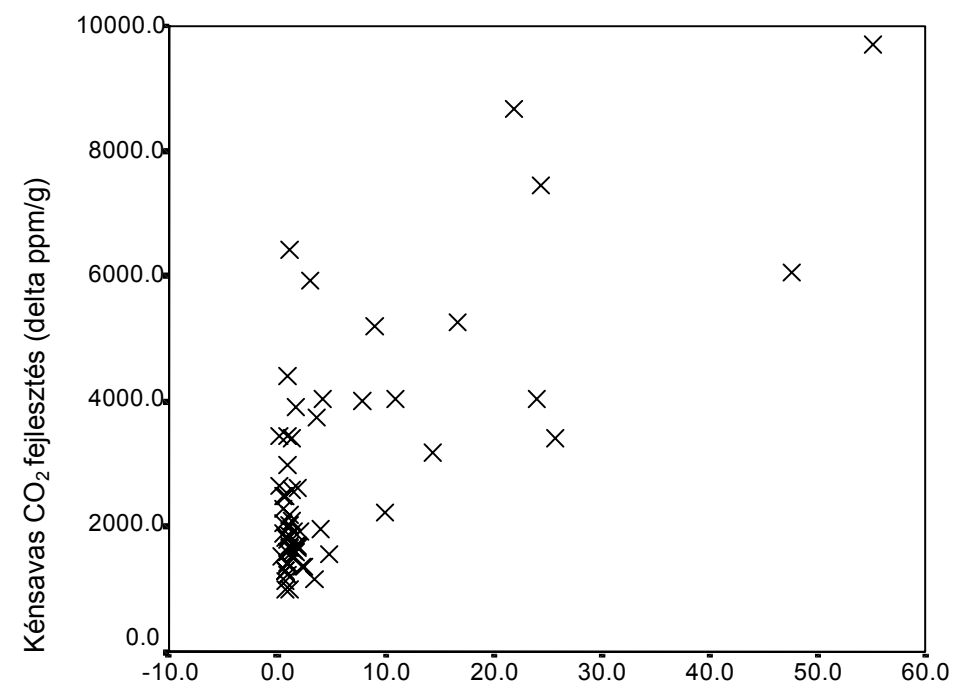

$\mathrm{CaCO}_{3} \%$ Scheibler-féle kalciméterrel

$$
\text { 6. ábra }
$$

Összefüggés a Scheibler-féle kalciméterrel mért $\mathrm{CaCO}_{3} \%$ és a kénsavas $\mathrm{CO}_{2}$-fejlesztés eredménye között

\section{5. táblázat}

A kálium-permanganátos $\mathrm{CO}_{2}$-fejlesztés és a Tyurin szerinti humusz \% között meghatározott korrelációs koefficiens az összes vizsgált mintára (A), ill. a $20 \%$-nál kisebb $\mathrm{CaCO}_{3}$-tartalmú minták (B) esetén

\begin{tabular}{|l|c|c|}
\hline \multirow{2}{*}{} & \multicolumn{2}{|c|}{$(1)$} \\
& \multicolumn{2}{|c|}{ Kálium-permanganátos $\mathrm{CO}_{2}$-fejlesztés } \\
\cline { 2 - 3 } & A. & B. \\
\hline a) Humusz \% Tyurin szerint & $0,756^{* *}$ & $0,811^{* *}$ \\
b) Log humusz \% Tyurin szerint & $0,666^{* *}$ & $0,711^{* *}$ \\
\hline
\end{tabular}

értelmezhető a szerves anyagból képződött kálium-permanganátos $\mathrm{CO}_{2}$-fejlesztés eredménye, mert több volt a karbonátból (kénsavas fejlesztés) fejlődött $\mathrm{CO}_{2}$, mint amennyi a szerves anyagból és a karbonátból együttvéve (káliumpermanganátos fejlesztés). Erre a magyarázat az lehet, hogy szerves anyag mérése esetén a kénsav felhígul, így ekkor nem képződik annyi $\mathrm{CO}_{2}$ a karbonátból, mint amikor csak kénsavat adunk a talajhoz. Nem zárható ki annak a lehetősége sem, hogy a kénsav csak a szervetlen karbonát oxidálására elfogy és már nem jut a szerves anyagra a szerves és szervetlen reakciók versenyzése miatt. A képződött szén-dioxid-koncentrációkból a reakcióegyenletek és az általános gáztör- 
vény alapján kiszámoltuk az oxidált szén mennyiségét. Átlagosan a Tyurin szerint meghatározott szerves anyag $0,7 \%$-a oxidálódik el az új módszerrel. Öszszehasonlítva a $\mathrm{CaCO}_{3}$-bontás esetén elért 12,5\%-os kinyeréssel megállapíthatjuk, hogy a szerves anyag meghatározására javasolt új terepi módszer esetén a reakció kis változásai, a minták heterogenitása stb. a meghatározott szerves-Ctartalom értékét erősen befolyásolják. A minták nem kellő homogenitása esetén a szervetlen karbonátok hatása erősebb, mint a szerves-C-tartalomé.

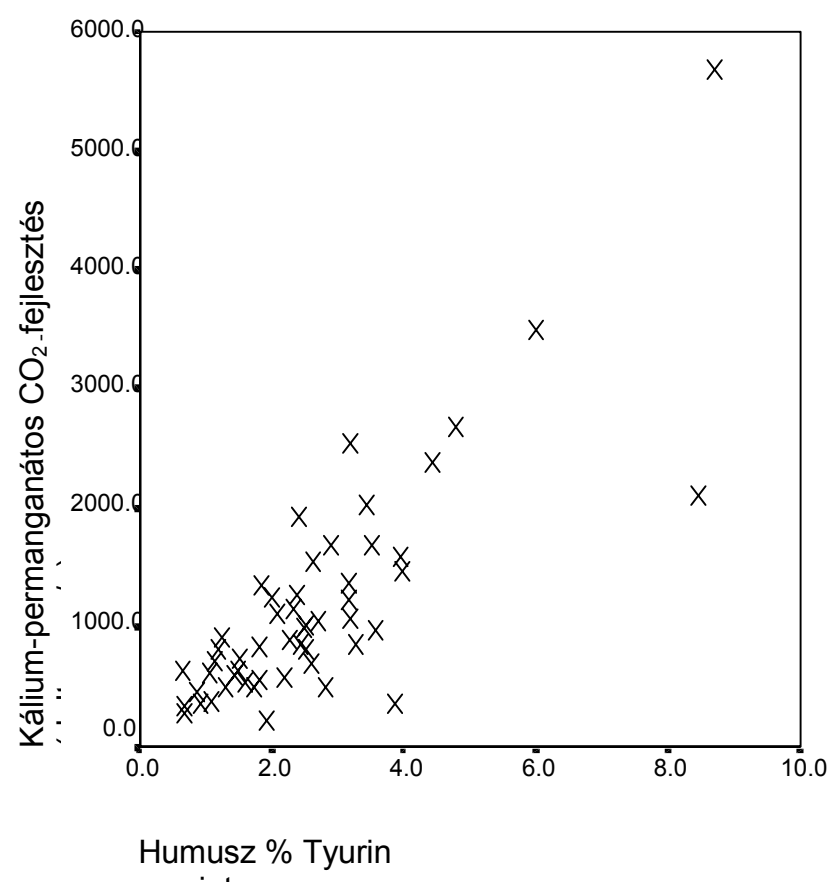

7. ábra

Összefüggés a kálium-permanganátos $\mathrm{CO}_{2}$-fejlesztés és a Tyurin szerinti humusz \% között, a $20 \%$-nál kisebb $\mathrm{CaCO}_{3}$-tartalmú minták esetén

Ha csak azokra a talajokra vizsgáljuk a korrelációt, amelyek karbonáttartalma $20 \%$-nál kisebb, akkor szorosabb összefüggést kapunk (5. táblázat, 7. ábra). A kisebb karbonáttartalom esetén javasolható a módszer terepi tesztelése az említett problémák kiküszöbölésével.

A 7. ábrához kapcsolódó, az origón átmenő egyenes regressziós egyenlete a következő: Humusz $(\%)=0,001922 \cdot$ Kálium-permanganátos $\mathrm{CO}_{2}$-fejlesztés (delta $\mathrm{ppm} / \mathrm{g}$ talaj); $\mathrm{R}=0,931$. 
A laboratóriumban kipróbált módszerek megbizhatóságának vizsgálata ismétlések alkalmazásával

Az ismétlésre kiválasztott 12 talajmintával a Tyurin szerinti, a terepi Walkley-Black, a lúgos EDTA és a kálium-permanganátos szén-dioxid-fejlesztéses módszerek megbízhatóságát vizsgáltuk. A különböző méréseket négy ismétlésben végeztük el. A módszerek megbízhatóságát a variációs koefficiens értéke alapján értékeltük (6. táblázat).

\section{6. táblázat}

A laboratóriumban tesztelt módszerek megbízhatósága 4-4 ismétlés alkalmazásakor

\begin{tabular}{|l|c|}
\hline \multicolumn{1}{|c|}{$\begin{array}{c}(1) \\
\text { Módszer }\end{array}$} & $(2)$ \\
\hline a) Humusz \% Tyurin szerint & Variációs koefficiens, \% \\
b) Terepi Walkley-Black sorrend ${ }^{+}$ & 5 \\
c) Terepi Walkley-Black abszorbancia & 4 \\
d) Lúgos EDTA sorrend & \\
e) Lúgos EDTA transzmittancia & 2 \\
f) Kálium-permanganátos $\mathrm{CO}_{2}$-fejlesztés (delta ppm/ & 31 \\
g talaj) & 38 \\
\hline
\end{tabular}

Megjegyzés: ${ }^{+}$: A színtónus alapján a legvilágosabbtól a legsötétebbig rendezett minták sorrendje

A legmegbízhatóbb módszernek a lúgos EDTA tekinthető abban az esetben, ha a minták sorrendjét vesszük figyelembe, utána következik a terepi WalkleyBlack abszorbancia, majd ezen módszer alapján a minták között felállított sorrend. Kevésbé megbízható a Tyurin-féle, a lúgos EDTA (ha a minták transzmittanciáját vesszük figyelembe) és a szén-dioxid-koncentráció mérésen alapuló módszer. A sorrendbe rakásos módszerek szóródása kicsi, következésképpen megbízhatóságuk jó, ugyanakkor kevéssé informatívak.

\section{Összefoglalás}

60 reprezentatív minta használatával olyan terepi módszereket hasonlítottunk össze laboratóriumban, amelyek alkalmasak a talaj szerves-C-tartalmának meghatározására. A módszereket a szabvány szerinti Tyurin-módszerrel összevetve értékeltük.

A talajminták színe, elsősorban a Munsell-féle színmélység (Value) szoros korrelációt $\left(\mathrm{R}=0,73^{* *}\right)$ mutatott a talajok humusztartalmának logaritmusával. Ez az összefüggés rámutat, hogy további vizsgálatokat érdemes folytatni a talajok szerves-C-tartalma és színe közötti részletes összefüggések feltárására. 
A terepi Walkley-Black módszer a laboratóriumi meghatározástól csak a szükséges reagensek mennyiségében tér el, így a vizsgálat során tömény kénsavas kálium-bikromáttal oxidáljuk el a szerves anyagot. A kénsav hozzáadásakor az oldat nagyon felmelegszik, ezért csak hűlés után önthető át kémcsőbe, ami az oldatok színének összehasonlítása miatt szükséges. A vizsgálat veszélyessége miatt a módszer nem alkalmas terepi alkalmazásra. Mind a terepi módszerrel meghatározott abszorbancia $\left(\mathrm{R}=0,73^{* *}\right)$, mind a minták abszorbancia szerinti sorrendje $\left(\mathrm{R}=0,87^{* *}\right)$ szoros korrelációt mutatott a Tyurin-módszerrel kapott humusztartalommal.

A humusztartalom logaritmusa és a lúgos EDTA transzmittancia között $0,78 * *$ volt a korrelációs koefficiens értéke. A vizsgálatok során kitünt, hogy egyes talajalkotók $\left(\mathrm{CaCO}_{3}\right.$, vas- és alumínium-oxidok) megváltoztatják az oldat színét és így zavarják a szervesanyag-becslést.

$\mathrm{Az}$ újonnan kidolgozott kálium-permanganátos szén-dioxid-fejlesztéses módszer lényege a talaj savas kálium-permanganát oldattal történő kezelése, majd a lefedett edényben három perc elteltével a képződött szén-dioxidkoncentráció műszeres mérése. A helyszíni szén-dioxid-mérést infravörös érzékelővel müködő hordozható berendezéssel végezzük. A talaj szervetlen karbonáttartalmának hatását párhuzamos, kálium-permanganát hozzáadása nélkül végzett reakcióval vesszük figyelembe. A Tyurin-módszerrel kapott humusztartalom és a módszer alkalmazása során képződött $\mathrm{CO}_{2}$-tartalom közötti korrelációs koefficiens $0,76^{* *}$ volt, a $20 \%$-nál kisebb karbonáttartalmú minták esetén pedig $0,81^{* *}$. Az új módszer továbbfejlesztéséhez tervezzük a talajhoz adott kénsav és víz mennyiségének olyan megválasztását, hogy a karbonát- és szervesanyag-meghatározás esetén a végeredmény ugyanolyan kénsavkoncentráció legyen. A 12,5\%-os karbonát- és $0,7 \%$-os szerves-C-visszanyerést szintén javítani kell, hogy a minták heterogenitása esetén a két szénforrás nagyon különböző hatása kevésbé érvényesüljön a meghatározás folyamán.

A módszerek megbízhatóságát 12 kiválasztott minta négy ismétlésben történt vizsgálata alapján, a variációs koefficiens alkalmazásával értékeltük. A sorrenden alapuló módszerek mutatták a legkisebb variációs koefficienst, majd a terepi Walkley-Black, Tyurin szerinti humusz, lúgos EDTA transzmittancia és a kálium-permanganátos $\mathrm{CO}_{2}$-fejlesztéses módszer egyre nagyobbat.

A laboratóriumban összehasonlított módszerek alkalmazhatóságát a terepen fogjuk véglegesen tesztelni.

A munkát az OTKA T 37731 számú kutatási témája keretében végeztük. További segítséget kaptunk az NKFP-4/030/2001 projekttől és a B-11/02 számú kétoldalú kormányközi TéT projekttől.

Kulcsszavak: humusz, hordozható szén-dioxid-mérő müszer, kálium-permanganátos $\mathrm{CO}_{2}$-fejlesztés, lúgos EDTA módszer, terepi Walkley-Black módszer 


\section{Irodalom}

BALLENEGGER R., 1958. Talajvizsgálati módszerkönyv. Mezőgazdasági Kiadó. Budapest.

BarabančíkovÁ, G., Senesi, N. \& BrunetTI, G., 1997. Chemical and spectroscopic characterization of humic acids isolated from different Slovak soil types. Geoderma. 78. 251-266.

Blume, H. P. \& HelsPer, M., 1987. Schätzung des Humusgehaltes nach der MunsellFarbhelligkeit. Z. Pflanzenernähr. Bodenk. 150. 354-356.

Bowman, R. A., 1997. Field Methods to Estimate Soil Organic Matter. Conservation Tillage Fact Sheet \#5. USDA-ARS and USDA-NRCS. Akron, CO.

Bowman, R. A., Guenzi, W. D. \& SAVORY, D. J., 1991. Spectroscopic method for estimation of soil organic matter. Soil Sci. Soc. Am. J. 55. 563-566.

BuZÁs I. (szerk.), 1988. Talaj- és agrokémiai vizsgálati módszerkönyv. 2. Mezőgazdasági Kiadó. Budapest.

CSAPÓ M. J. \& CSAPÓ I. J., 1980. Talaj és termelés. Ceres. Bukarest.

Environmental Instruments, 1988. Anagas CD 98 Operating Instructions. Environmental Instruments. Leamington, UK.

GieseKIng, J. E., 1975. Soil Components. Volume 1. Organic Components. SpringerVerlag. New York

Hodgson, J. M., 1974. Soil Survey Field Handbook. Rothamsted Experimental Station. Harpenden, Herts.

MiCHÉLI, E., 2003. Carbon sequestration in agricultural ecosystems. In: Workshop Abstracts, 2-6 June, 2003. 1-41. SZIE. Gödöllö.

NÉMETH T., 1996. Talajaink szervesanyag-tartalma és nitrogénforgalma. MTA Talajtani és Agrokémiai Kutató Intézete. Budapest.

OrLOV, D. S., 1985. Humus Acids of Soils. Russian Translation Series, A.A. Balkema. Rotterdam.

PATAKI L. \& ZAPP E., 1972. Analitikai kémia. Tankönyvkiadó. Budapest.

SCHEFFER, F. \& SchachtschaBel, P., 1976. Lehrbuch der Bodenkunde. Ferdinand Enke Verlag. Stuttgart.

Stevenson, F. J., 1982. Humus Chemistry. John Wiley \& Sons. New York.

SzABOLCS I., 1966. A genetikus üzemi talajtérképezés módszerkönyve. Országos Mezőgazdasági Minőségvizsgáló Intézet. Budapest.

SZERÉNYI G., 1982. Biológiai terepgyakorlatok a gimnázium III. és IV. osztálya számára. Tankönyvkiadó. Budapest.

USDA, 1996. Soil Survey Laboratory Methods Manual. Soil Survey Investigations Report No. 42. Version 3. USDA. Washington, D. C.

WAlkley, A. \& Black, I. A., 1934. An examination of the Degiareff method for determing SOM and a proposed modification of the chromic acid titration method. Soil Sci. 37. 29-38.

Érkezett: 2003. július 20. 


\title{
Method for the Rapid Field Determination of Soil Organic Carbon Content
}

\author{
T. TÓTH and B. SZABÓ
}

Research Institute for Soil Science and Agricultural Chemistry of the Hungarian Academy of

Sciences, Budapest and Institute of Environment Management, Faculty of Agricultural and Environmental Sciences, Szent István University, Gödöllő (Hungary)

\begin{abstract}
Summary
With the use of 60 representative samples, a laboratory comparison was made of field methods suitable for the determination of soil organic $\mathrm{C}$ content. The methods were evaluated by comparing them with the standard Tyurin method.

The colour of the soil samples, especially the value read from the Munsell Colour Chart, exhibited a close correlation $\left(\mathrm{R}=0.73^{* *}\right)$ with the logarithm of the soil humus content. This indicates that it would be worth carrying out more detailed studies on the correlations between organic $\mathrm{C}$ content and soil colour.

The field Walkley-Black method differs from the laboratory technique only in the quantity of reagents applied, so the organic matter is oxidized using potassium bichromate in concentrated sulphuric acid. When the sulphuric acid is added, the solution heats up considerably, so it must be cooled before being poured into test-tubes for a comparison of the colour of the solutions. As this method is dangerous it is not really suitable for field use. Both the absorbance measured using the field method $(\mathrm{R}=$ $\left.0.73^{* *}\right)$ and the order of the samples on the basis of absorbance $\left(\mathrm{R}=0.87^{* *}\right)$ exhibited a close correlation with the humus content determined using the Tyurin method.

There was a correlation coefficient of $0.78^{* *}$ between the logarithm of the humus content and the basic EDTA transmittance. It was observed during the investigations that certain soil components $\left(\mathrm{CaCO}_{3}\right.$, iron and aluminium oxides) modified the colour of the solution, thus interfering with organic matter estimation.

The newly elaborated method involves treating the soil with acidic potassium permanganate solution, followed by the measurement of the carbon dioxide concentration formed over a period of three minutes, using a portable instrument with an infrared detector. The inorganic carbonate content of the soil is measured separately with the addition of sulphuric acid only. The correlation coefficient between the $\mathrm{CO}_{2}$ content recorded with the potassium permanganate method and the Tyurin humus content was $0.76^{* *}$, while it was $0.81^{* *}$ for soil samples having less than $20 \%$ carbonate. Further improvement of the new method will be based on modifying the amount of sulphuric acid and water in such a manner that the concentration of acid during the determination of carbonates and organic matter should be the same. The present recovery rates of $12.5 \%$ for carbonate and $0.7 \%$ for organic carbon must also be improved in order to decrease the very different effects of the two carbon sources during the determination in the case of sample inhomogeneity.

The reliability of the methods was tested by analyzing 12 samples in 4 replications using the coefficient of variation (CV). The smallest CV was obtained for methods based on the order of soil organic carbon values, followed by the Walkley-Black, Tyurin, basic EDTA and potassium permanganate methods.
\end{abstract}


The final comparison of the methods screened in the laboratory will be carried out in the field.

Table 1. Basic statistical parameters of the 60 analyzed samples. (1) Method. a) Dry Munsell Value; b) dry Munsell Chroma; c) moist Munsell Value; d) moist Munsell Chroma; e) organic carbon \% by dry combustion; f) humus \% according to Tyurin; g) field Walkley-Black absorbance; h) field Walkley-Black order; i) basic EDTA order; j) basic EDTA transmittance; k) $\mathrm{CaCO}_{3} \%$ using Scheibler's calcimeter; 1) sulphuric acid $\mathrm{CO}_{2}$ production, ppm; m) potassium permanganate $\mathrm{CO}_{2}$ production, delta ppm/g soil; n) log humus \%, according to Tyurin. (2) Minimum. (3) Maximum. (4) Mean. (5) Deviation. Note: * Parameter determined using the Munsell colour chart; ** Order of samples from the lightest to the darkest colour tone.

Table 2. Correlation coefficients between the soil humus content (according to Tyurin) and the soil colour. (1) Parameter. a) humus \%; b) log humus \%; c) moist Munsell Value; d) dry Munsell Value; e) moist Munsell Chroma. (2) Moist. (3) Dry. (4) Munsell Value. (5) Munsell Chroma. Note: **, *: significant at the 0.01 and 0.05 levels of probability, respectively; ${ }^{+}$parameter determined using the Munsell colour chart.

Table 3. Correlation coefficients between the soil humus contents determined using the field Walkley-Black method and the Tyurin method for all the samples (A) and for those with humus contents of less than 2.5\% (B). (1) Parameter. a) Humus \% according to Tyurin; b) log humus \% according to Tyurin; c) and (2) Field Walkley-Black absorbance. (3) Field Walkley-Black order. Note: see Table 1.

Table 4. Correlation coefficients between the soil humus contents determined using the basic EDTA method and the Tyurin method for samples with humus contents of less than 2.5\%. a)-b): see Table 3. c) and (1) basic EDTA transmittance; d) and (2) log basic EDTA transmittance. (3) Basic EDTA order. Note: see Table 1.

Table 5. Correlation coefficients between soil humus contents determined using the potassium permanganate method and the Tyurin method for all the samples (A) and for those with humus contents of less than $2.5 \%$ (B).

Fig. 1. Histogram of soil humus content determined by the Tyurin method without (A) and with (B) logarithm transformation.

Fig. 2. Correlation between the moist Value read from Munsell Colour Charts and the logarithm of the soil humus content according to Tyurin.

Fig. 3. Correlation between the order of samples determined by the field WalkleyBlack method and the soil humus content according to Tyurin.

Fig. 4. Correlation between the absorbance of samples determined by the field Walkley-Black method and the soil humus content according to Tyurin for samples with humus contents of less than $2.5 \%$.

Fig. 5. Correlation between transmittance determined by the basic EDTA method and the logarithm of the soil humus content according to Tyurin.

Fig. 6. Correlation between the $\mathrm{CaCO}_{3} \%$ determined with the Scheibler calcimeter and the results of the sulphuric acid $\mathrm{CO}_{2}$ production method.

Fig. 7. Correlation between the $\mathrm{CO}_{2}$ production in the potassium permanganate method and the soil humus content according to Tyurin for samples containing less than $20 \% \mathrm{CaCO}_{3}$. 